Article

\title{
One Health, One World-The Intersecting Legal Regimes of Trade, Climate Change, Food Security, Humanitarian Crises, and Migration ${ }^{\dagger}$
}

\section{Kelli K. Garcia and Lawrence O. Gostin *}

O’Neill Institute for National and Global Health Law, Georgetown University Law Center, Washington, DC 20001, USA; E-Mail:kkg28@law.georgetown.edu

* Author to whom correspondence should be addressed; E-Mail: gostin@law.georgetown.edu.

$\dagger$ This article is based on Lawrence O. Gostin, Global Health Law: International Law and Global Institutions (Cambridge: Harvard University Press, Forthcoming 2013).

Received: 27 February 2012; in revised form: 14 March 2012 / Accepted: 19 March 2012 /

Published: 4 April 2012

\begin{abstract}
Today's global health challenges require a multi-sectoral approach in which health is a fundamental value within global governance and international law. "One Health, One World" provides a unified, harmonious vision of global health governance that supports the wellbeing of humans and animals living in a clean and temperate environment. This article focuses on five legal regimes - trade law, food security law, environmental law, humanitarian law, and refugee law - that play a pivotal role in influencing health outcomes and are integral to achieving the One Health, One World vision. International trade, for example, opens markets not only to life-saving products such as vaccines, medicines, and medical equipment, but also to life-threatening products such as tobacco and asbestos. If strengthened and enforced, environmental law can decrease air and water pollution, major causes of death and disability. World hunger has been exacerbated by the global economic crisis and climate change, increasing the urgency for international law to enhance food security. Humanitarian law must similarly be strengthened to protect civilians adequately as the nature of warfare continues to change. Refugee law plays a pivotal role in protecting the health of deeply vulnerable people who lack food, shelter, and social stability. Higher standards and more effective compliance are necessary for international law to realize its full potential to safeguard the world's population.
\end{abstract}


Keywords: global health; trade law; food security law; environmental law; humanitarian law; refugee law

\section{Introduction}

The field of law has, in many ways, been the poor relation in the worldwide effort to deliver a cleaner, healthier and ultimately fairer world. We have over 500 international and regional agreements, treaties and deals covering everything from the protection of the ozone layer to the conservation of the oceans and seas.... But unless these are complied with, unless they are enforced, then they are little more than symbols, tokens, paper tigers.

Klaus Töpfer, 2002 [1]

The articles in this founding issue of Laws each examine a major disciplinary area commonly taught in law schools and litigated in courts - ranging from contracts and torts to administrative, constitutional and international law. Although it is certainly instructive and customary to deal with a single body of law, legal and social outcomes are influenced more broadly through a complex interplay of governance arrangements.

To illustrate and reinforce this point, we conclude this volume of Laws with a careful examination of a major area of legal and social policy_-global health. This is a field of growing importance, not only because health has transcending value to individuals and communities, but also because it has become so strikingly clear that improving health and closing health inequalities require policy makers and advocates to attend to a wide variety of legal regimes - both national and global. Here we focus on international legal solutions for improving health outcomes, but we also want to stress the equal importance of national public health law and regulation.

International law can profoundly affect global health - for better or worse. Health is not the product of health systems alone but is rather the result of policies and practices in a whole host of legal arenas, including trade law, environmental law, food security law, humanitarian law, and refugee law. The title of this article, "One Health, One World [2,3]", best expresses the unified, harmonious goal of global health governance - the wellbeing of humans and animals living in a clean and temperate environment [4]. This is a vision that stresses the interconnectedness of multiple legal regimes that significantly impact global health.

Health threats - ranging from infectious and noncommunicable diseases to injuries - cannot be ameliorated by states acting alone. Nor can traditional health law and governance solve them. Instead, today's global health challenges require a multi-sectoral approach in which health is a fundamental value within global governance and international law. International law must be expanded, strengthened, and faithfully implemented, with health placed nearer the center of its mandate in order to improve wellbeing and lifespans. Although numerous legal regimes affect public health, including labor and narcotics, this article focuses on five - trade law, food security law, environmental law, humanitarian law, and refugee law. Each legal discipline plays a pivotal role in influencing health outcomes. 
The 2011 famine in the Horn of Africa exemplifies how these intersecting legal regimes influence global health - all playing a role in how people fared during the worst drought in 60 years. A 20 year-long civil war in Somalia and concomitant breakdown in infrastructure dramatically worsened the drought's impact, leaving millions malnourished and starving, with mass migrations to refugee camps in Kenya and Ethiopia [5,6]. Millions risked starvation with $>30 \%$ of children acutely malnourished. The rebel group al-Shabab diverted water from subsistence farmers to commercial farms that provided support for their armies. Once they took control of the region, they had little interest in governing, blocked foreign aid, and refused to allow people to leave in search of food $[7,8]$.

As a result of the drought and war, almost 3,000 people fled war-torn Somalia each day to Kenya and Ethiopia, precipitating a humanitarian crisis, just as the region faced an unrelenting drought. The public health effects of the refugee crisis were devastating. In the Dallo Ado refugee camp, the mortality rate among children was as high as 15 per 10,000 per day [9]. Ethiopian refugee camps suffered measles outbreaks. "The mix of measles and high levels of malnutrition can be fatal," the agency warned [10]. In one day alone, 800 refugee children were transported to medical centers in Mogadishu [11].

Trade agreements, climate change, food security, armed conflicts, and migration are key determinants of health - an integral part of global governance for health. Their importance to health is increasing with the rapid growth in urbanization, population, and globalization. Unfortunately, the driving forces behind these legal regimes - commercial, economic, and geostrategic — are often in tension with public health. The five intersecting regimes must be strengthened, so they protect and promote, rather than detract from, major health goals. Without higher standards and more effective compliance, international law will fail to realize its full potential to safeguard the world's population, particularly for the most vulnerable people.

This article begins with a discussion of trade, which is perhaps the single most developed area of international law. The international trade in goods and services is pervasive, traversing both political and geographic boundaries. The movement of products, services, and knowledge along routes of trade is the engine that drives economies, but it is also the means by which disease is spread and cultures homogenize. Trade provides countries with resources and technological advances to which they would not otherwise have access.

International trade opens markets not only to life-saving products such as vaccines, medicines, and medical equipment, but also to life-threatening products such as tobacco or asbestos. Trade agreements also can make essential medicines, such as anti-retroviral medication for HIV/AIDS, so expensive that they are out-of-reach for the poor. Trade in services can reallocate expertise where it is needed while draining another area of its human capital. International trading systems can (for better or worse) change the way states regulate their products $[12,13]$.

The article continues with one of the defining issues of our time - the environment. Climate change threatens health and security everywhere, including increasing the range of disease-carrying mosquitoes, threatening food security, increasing the severity and frequency of extreme weather events, and pushing populations to the edge of survivability. Environmental law has the potential to decrease air and water pollution, major causes of death and disability, and to preserve biodiversity, with its promise for developing the innovative medicines of tomorrow. 
The third section turns to a critical field intersecting with health and the environment - food security. The affordability and availability of sufficient nutritious food for a growing world population depends on multiple factors, including trade, subsidies, land use, and food aid. Despite the goal to reduce the number of people living in hunger, more people were undernourished in 2010 than in 1996, when the World Food Summit established its goal. The global economic crisis, climate change, and armed conflicts have all exacerbated world hunger, making it all the more urgent to harness international law to enhance food security.

The fourth section moves from a nascent legal regime to one of the oldest, humanitarian law. With 19th century origins, humanitarian law aims to minimize the human cost of war-protecting civilians, wounded soldiers, and health personnel. More recently, arms control treaties aim to protect people against inhumane instruments of destruction (nuclear weapons, cluster bombs, and land mines), whose impact can be felt even in times of peace.

The fifth section examines the connections between forced migration and health. Mass migration is a hallmark of globalization, exacerbated by extreme weather events, famine, and armed conflict. Refugee law is of particular significance, considering its major role in protecting the health of deeply vulnerable people who lack food, shelter, and social stability.

Finally, the conclusion encourages scholars, policy makers, and civil society to place greater importance on a multi-sectoral approach to global health governance in which health is a central value underlying a variety of legal regimes. Global health advocates must therefore develop expertise in wide range of legal sectors and in order to effectively advocate for the "One Health, One World" approach to global health governance. According to UN Secretary-General BAN Ki-moon, "We need to chart a new, more sustainable course for the future, one that strengthens equality and economic growth while protecting our planet [14]." Those concerned with global health must be at the forefront of these efforts, expanding their expertise beyond the traditional health domains in order to effectively advocate an approach that places health at the center of these intersecting legal regimes.

\section{Global Health and International Trade}

Too much of this century was marked by force and coercion. Our dream must be a world managed by persuasion, the rule of law, the settlement of differences peacefully within the law and cooperation. It's a good thing that all our living standards are now based on the ability of our neighbours to purchase our products. That's where the WTO can do splendid work and advance the progress of the human species.

Mike Moore, former WTO Director-General [15]

Increased trade liberalization, a driving force behind globalization, brings new opportunities and challenges for global health. Trade liberalization may well improve economic prosperity generally and thereby fuel development and improve health outcomes. Increased trade in health-related goods, services, and people (e.g., patients and professionals) offer myriad benefits for the public's health [16]. Nevertheless, there remain deep concerns that the trade system favors the global north, while impeding development and health in the global south. For those concerned with equity and social distribution, 
there is a fear that trade liberalization places rich countries and multinational corporations' interests ahead of the health and lives of the world's poor.

Currently, governance of trade depends on a complex and overlapping web of international, regional, and bilateral rules for trade and health. The World Trade Organization (WTO) serves as the multilateral organization for trade, but its rules significantly affect global health. Together, WTO agreements form a rule-based system within which WTO members must operate. Some agreements provide certain rule "flexibilities" that can be exercised to safeguard the public's health. Other agreements allow countries to restrict trade for the purposes of protecting health, while barring trade discrimination through such practices [12,17-21]. Beyond the WTO, a "spaghetti bowl" of bilateral and regional free trade agreements (FTAs) have formed across the globe [22]. These separately negotiated trade agreements often weaken health protections or flexibilities built into WTO's multilateral treaties.

What seems clear is that trade rules, even when taking health into account, are primarily designed to facilitate trade, which needs a counterbalancing voice. "One Health, One World" requires that health be not simply taken into account, but rather that health and development should be central purposes of trade agreements. This section elucidates the complex relationship between global health and international trade, highlighting how health can be an important factor in trade agreements and dispute resolution.

\subsection{The World Trade Organization}

The WTO was established on January 1, 1995 with the objective of "raising standards of living, ensuring full employment, ... and expanding the production of and trade in goods and services, while allowing for the optimal use of the world's resources [for] sustainable development ... [and ensuring] that developing countries ... secure a share in the growth in international trade [23]". The WTO founders, therefore, intended trade expansion to benefit health and development in low and middle-income countries. Yet, nearly two decades later, there remains bitter controversy over the effects of trade on health, the environment, and economic development for the poor.

Importantly, non-state actors can exercise influence at the WTO. International organizations, such as the World Health Organization (WHO) and the Food and Agriculture Organization (FAO), have been granted observer (or ad hoc observer) status in specific WTO councils and committees. For instance, the WHO holds observer status in the WTO Ministerial Conferences and on the Sanitary and Photosanitary (SPS) Committee as well as ad hoc observer status on the Council for Trade in Services and the Council for Trade-Related Aspects of Intellectual Property Rights [24]. Likewise, the WTO has held observer status at the World Health Assembly, Framework Convention on Tobacco Control (FCTC) negotiations, and the joint WHO-FAO Codex Alimentarius Commission (Codex).

Civil society similarly has a vested interest in the WTO. The Marrakesh Agreement (1994) called upon the WTO to take "appropriate arrangements for consultation and cooperation with nongovernmental organizations" and, in 1996, the General Council adopted guidelines to clarify its relations with nongovernmental organizations (NGOs) [23,25]. In the WTO's early years, the organization was criticized for not fully engaging civil society by institutionalizing relationships or giving NGOs a meaningful voice in shaping WTO decisions. The WTO's problems of unequal access, 
shallow relations, and limited reciprocity in civil society dialogue posed barriers to WTO transparency, effectiveness, and accountability [26].

Efforts have been made since then to improve NGO relations and, thus far, the WTO's arrangements with civil society have taken the form of permitting attendance at Ministerial Conferences and issue-specific symposia as well as holding regular meetings with WTO staff. The WTO also provides briefings to NGOs and circulates NGO position papers to members [27]. However, these efforts remain relatively weak and without greater civil society engagement, public health and global justice will not be placed at the forefront of WTO's agenda

\subsection{WTO Agreements in Relation to Health}

Health impacts can affect the interpretation and implementation of WTO agreements, while WTO agreements can have a significant impact on health. The complex interactions between health and trade rules are centrally important to global governance for health. The WTO agreements must ensure a fair balance between health and trade, while also lifting countries from poverty and ill health. This section explores WTO agreements in relation to health and country disputes over their application.

\subsubsection{The Free Trade in Goods and the Protection of Health and Safety}

The free trade in goods can spread health and safety hazards widely and rapidly. This may require states to restrict the international trade of goods to protect human, animal or plant health and life within their national boundaries. However, when not justified by health and safety concerns, such restrictions act as disguised non-tariff barriers, which improperly disrupt and limit trade. Health and safety concerns are governed specifically by the Agreement on Technical Barriers to Trade (TBT Agreement) and the Agreement on the Application of Sanitary and Phytosanitary Measures (SPS Agreement). The challenge in applying these WTO agreements is to protect health and safety without unduly obstructing trade or covertly resorting to trade protectionism.

The General Agreement on Tariffs and Trade (GATT) deals with trade in goods. Its primary purpose is "to constrain governments from imposing or continuing a variety of measures that restrain or distort international trade [28]". Although the GATT prohibits discrimination according to Most Favored Nation (MFN) and national treatment obligations, Art. XX explicitly allows discrimination by WTO members when it is "necessary to protect human, animal or plant life or health." However, the actions taken cannot constitute "arbitrary or unjustifiable discrimination between countries ... or a disguised restriction on international trade." The lack of clarity has provoked tense trade disputes. For example, in the Thailand-Cigarettes case, the US disputed Thailand's Tobacco Act 1966, which imposed import restrictions and taxes on foreign cigarettes, claiming inconsistency with the GATT 1947 [17]. Thailand responded that US cigarettes contained "chemicals and other additives ... [that] might make them more harmful to human health than Thai cigarettes" and, therefore, import restrictions were justified for public health purposes. A WHO submission to the dispute panel indicated there was no scientific evidence to prove that foreign cigarettes were more harmful than Thai cigarettes; American cigarettes, however, were easier to smoke (due to additives and flavoring), leading to the false impression that they were safer $[29,30]$. 
The GATT panel determined that Thailand's act violated GATT and that its import restrictions were not "necessary" under Art. XX(b). The panel believed that Thailand could have protected the public's health without discriminating against foreign cigarettes. However, the panel upheld Thailand's Tobacco Act advertising ban because it applied to all cigarettes.

The TBT Agreement, which applies to regulations governing "product characteristics or their related processes or production methods" (Annex 1, \1), permits trade restrictions for "legitimate objectives," namely the protection of human health or safety, animal or plant life or health, national security requirements, the prevention of deceptive practices, or environment protection [31]. It also requires that such barriers - often in the form of technical requirements such as product standards, testing, or certification procedures-not create unnecessary obstacles to trade or be more severe than needed to accomplish their legitimate purposes (also known as proportionality).

The TBT Agreement has also been at the center of heated trade disputes concerning health. In the Indonesia-US Clove Cigarettes, Indonesia brought a WTO complaint against the United States for banning the sale of clove cigarettes, while failing to ban menthol cigarettes. Although any cigarettes pose serious health risks, Indonesia argued that clove cigarettes (mostly imported from Indonesia) and menthol cigarettes (mostly produced in the US) were "like products." On September 2, 2011, the WTO panel rejected Indonesia's claim that the measure was more trade restrictive than necessary to protect human health. Despite its finding that the ban on Clove cigarettes was a valid public health measure, the panel held that the US violated the principle of non-discrimination, finding that clove and menthol cigarettes were "like" in terms of the regulatory objective of reducing youth smoking. The U.S. is appealing the ruling.

The Framework Convention on Tobacco Control (FCTC) demands tobacco reduction strategies (e.g., pricing, taxation, and regulation of contents, disclosures, and labeling) and supply reduction strategies (e.g., restrictions on illicit trade in tobacco products and sales to minors) potentially conflict with WTO agreements [32]. A WTO member, for example, could challenge state limits on nicotine content, even though Article 9 of the FCTC requires regulation of the contents of cigarettes. Given the "arbitrary nature of setting specific limits on the nicotine contents of cigarettes," such regulations could be challenged as "arbitrary and unjustified [33]." Yet a WTO panel is likely to find in favor of the defending state party if the adopted standard conforms to an internationally accepted standard. (If a country were to apply a measure exceeding international standards, the TBT would require the country to meet additional requirements.) Another contentious FCTC measure that could be challenged under the GATT is the use of tobacco marketing bans. Although a GATT panel in the Thailand Cigarettes case found that Thailand's advertising ban was permissible under GATT Art. XX(b), future GATT panels could find trade violations under different circumstances [34].

A troubling aspect of the FCTC is that it does not clearly specify parties' obligations in relation to international trade law. Although the FCTC preamble states that governments will give priority to public health, it does not expressly specify what health should take priority over. Article 2 is the conflicts clause, but it merely authorizes member states to adopt measures beyond those required by the Convention, provided they are "consistent" with international law. States may enter bilateral or multilateral agreements on tobacco-related matters that are "compatible" with Convention obligations. Yet, the FCTC does not specify what might be consistent or compatible. 
In the absence of a FCTC provision addressing conflicts with earlier treaties, the general rule is that the later treaty later prevails. However, another rule is that the treaty with "greater specificity" prevails. The "last-in-time" and "specificity" rules suggest that the FCTC could be prevail over earlier, less-explicit trade-related agreements, despite the FCTC being silent on this issue. However, if one of the disputing parties is not a party to the FCTC, the treaty to which both disputants are parties will govern their legal relations.

The deep tensions between health and trade, as illustrated by the China-Poultry case, discussed below, remain a serious problem today. The problem is multifaceted and only increases the fissure between the global north and south. First, powerful countries may insist that developing countries accept their products even in the face of genuine health concerns, such as the US challenging Thailand's cigarette import ban. Second, as developed countries increasingly open their doors to products from resource-poor countries, they are demanding more stringent safety standards to satisfy domestic consumers. This can place a substantial and disproportionate strain upon poorer countries, which often lack the infrastructure and resource capacity to implement and enforce foreign safety standards [30,35].

At the same time, widely divergent regulatory standards among WTO members raise concerns for developed and developing countries alike. Greater harmonization of health and safety standards could relieve trade tensions among states, but this will require more effective developing country partnerships in setting international standards as well as technical and capacity support in implementing harmonized standards [30].

In 2006, the US Department of Agriculture's Food Safety Inspection Service (FSIS) determined that China's meat and poultry processing standards were sufficient to permit importation to the US. However, Congress later prohibited the FSIS from using public funds to implement the rule, effectively banning Chinese poultry imports. Advocates of the ban pointed to major regulatory deficiencies in China including the inconsistent exercise of control over food processing plants, a lack of enforcement of safety standards, and inadequate testing for bacteria and residues. The ban stayed in effect until November 2009 [36,37].

China challenged the US funding ban under the GATT 1994, the SPS Agreement, and the WTO Agreement on Agriculture. Alleged breaches included a failure to comply with the GATT 1994 MFN requirement and a lack of scientific evidence or adequate risk assessment to support the ban as required under the SPS Agreement. The US defended the funding restriction as a "measured reaction" to China's food safety enforcement problems, which fell within the exceptions for measures necessary to protect human and animal life or health.

A WTO Panel report on September 29, 2010, found that the US violated international trade laws. Most notably, the US refusal to apply normal approval procedures for Chinese imported poultry products constituted arbitrary and unjustifiable discrimination. The Panel also found that there was "no scientific evidence, risk assessment, or other justification for treating Chinese poultry products differently from those of other WTO Members." The outcome of this dispute indicates that the use of trade restrictions for public health purposes must be justified by ongoing scientific assessment and review under WTO rules.

The WTO Appellate Body has also made it clear that health concerns are relevant in interpreting and applying the basic principles of international trade. In the EC-Canada Asbestos Case (2001) [38] 
the Appellate Body upheld a French regulation prohibiting the manufacture, domestic sale, and import of asbestos-containing products. The Appellate Body stressed that human health is "important to the highest degree" and noted the strong scientific evidence that asbestos fibers were toxic (causing asbestosis, lung cancer, and mesothelioma), whereas similar fibers were not. Based on this distinction, they held that products containing asbestos were not "like" similar products containing other fibers. Therefore they could properly be excluded without violating national treatment obligations. In addition, France's import ban was found to be necessary for the protection of human life and no reasonably available alternative measures were identified. Consequently, the ban was found to be in accordance with the exception for health matters contained in GATT Art XX(b).

Notably, the revised International Health Regulations (2005) [39], which provides (1) routine public health protection - ongoing surveillance and response to disease threats within countries and at their borders, and (2) coordinated and proportionate global detection and control of transnational disease threats [40], was drafted to complement WTO law [41]. Article 43 of the IHR reflects the SPS criteria: no more restrictive of trade than necessary to protect health, measured by available scientific evidence of risk, and based on international standards. Similarly, "by calibrating health and trade interests, the IHR resonate with international trade law ... which also recognizes the state's right to restrict trade for health purposes but limits this right to ensure that restrictions are necessary [42]".

\subsection{The Protection of Intellectual Property Rights and its Implications for Public Health}

Intellectual property (IP) protection gives creators incentives to generate ideas to benefit society as a whole. At the same time, by giving creators exclusive rights to exploit their inventions, designs, or other ideas, IP protection can make products unaffordable. It is for that reason that IP rights are so politically contentious [43]. To entrepreneurs, IP protection is indispensable to scientific innovation and the long-term public good. Biotechnology companies claim that exclusive rights to new drugs or vaccines are needed to recoup the high costs of research and development. IP protection can, however, make essential medicines prohibitively expensive for the world's poorest people. Advocates believe that it is unacceptable when countless people die of AIDS or other treatable diseases out of respect for the IP rights of private companies.

Ideas and knowledge have emerged as an increasingly important part of international commerce and corporations have sought to ensure the protection of new inventions in global markets. The Agreement on Trade-Related Aspects of Intellectual Property Rights (TRIPS) establishes minimum levels of IP protection that each government must afford to rights holders, thus ensuring more uniformity and bringing national policies under international rules with a dispute settlement system. The central mission of TRIPS is to protect and enforce IP rights for "the promotion of technological innovation and ... the transfer and dissemination of technology, to the mutual advantage of producers and users of technological knowledge and in a manner conducive to social and economic welfare" (TRIPS Art. 7). Members, however, may adopt measures necessary to protect public health and nutrition, and to promote the public interest in sectors of vital importance to their socio-economic and technological development (TRIPS, Art. 8(1)).

Whether TRIPS achieves a fair balance between IP and health has been the subject of bitter dispute [18,44-46]. There has been intense debate over the treaty's effects on developing countries. 
Some poor countries currently do not possess the systems of education, manufacturing, and marketing to innovate and gain the benefits of IP protection [47]. To these nations, TRIPS may afford little advantage because they possess few, if any, patentable products. At the same time, TRIPS can make it difficult to produce or purchase affordable generic medications that people need desperately. Some economists estimate that a $\$ 60$ billion per-year transfer from poor to rich countries (composed of $\$ 40$ billion in patent payments and $\$ 20$ billion in copyright royalties) would occur if TRIPS were fully implemented - caused mainly by increased patent and royalty payments as well as higher prices [48].

The TRIPS Agreement contains significant "flexibilities" that can be exercised for the protection of the public's health. Most basic of all, members are free to determine the appropriate implementation of TRIPS within their own legal system (Art. 1) - for example, by setting a high bar for novelty and inventiveness, thus reducing the problem of evergreening patented medicines, the process of extending patents such as through patents for new uses, forms, and combinations of the medicines. TRIPS allows certain exclusions from patentability, such as diagnostic, therapeutic, and surgical methods (Art. 27.3(a)), and limited exceptions to the exclusive rights conferred by a patent. TRIPS flexibilities should enable countries to fashion a TRIPS-compliant intellectual property regime.

However, developing countries have found it difficult to exercise TRIPS flexibilities due to the treaty's technical complexity and strong political pressure from developed countries and pharmaceutical companies [49]. More critically, the devastation caused by the AIDS pandemic brought the shortcomings of TRIPS into stark relief. Patented drugs cost anywhere from 3 to 15 times their generic equivalents. Developing countries could not afford to pay the high costs of combination drug therapy for HIV/AIDS - even when civil society pressured pharmaceutical companies to lower prices in developing countries. As a result, the international community gradually became more sensitive to public health concerns, lessening international support for the stringent IP demands of the US and other industrialized countries.

This was apparent with the 2001 passage of the Doha Declaration on the TRIPS Agreement and Public Health, which reaffirmed the use of TRIPS flexibilities and stated that "the Agreement can and should be interpreted and implemented in a manner supportive of WTO members' right to protect public health and, in particular, to promote access to medicines for all” (Doha Declaration, para. 4).

While the Doha Declaration has been widely praised as a victory for developing countries, the growing developed country practice of negotiating "TRIPS-plus" measures through free trade agreements (FTAs) has undermined the Doha Declaration. For example, the U.S. has negotiated many bilateral and regional FTAs to implement a U.S.-type IP regime that does not recognize the tension between public health and intellectual property [50]. TRIPS-plus provisions can significantly undermine the ability of developing nations to protect the health of their citizens, beyond the already restrictive levels required by TRIPS [51]. The net effect of trade rules has been to impede access to affordable treatments for the world's most vulnerable people.

\subsection{The Balance Between International Health and Trade}

A quest for greater fairness, in income levels, in opportunities, in access to medicines and health services, has become a strategy for coping with the unique pressures of a globalizing world. In a world of radically increased interdependence, lives and opportunities, including 
prospects for better health, are governed by international systems that create benefits, yet have no rules that guarantee fair distribution of these benefits.

Margaret Chan, WHO Director-General [52]

Multilateral cooperation can be an empty gesture if it does not deliver actual, tangible results at the national level - in short, if it does not advance public health in what a WTO Appellate Body decision termed "the real world where people live and work and die."

Pascal Lamy, WTO Director-General [53]

At first glance, it might appear that there is an antagonist relationship between the objectives of international health and trade. Yet, success in both fields depends on mutually beneficial arrangements. A fair and vibrant trade system would raise the standard of living for everyone, which would achieve powerful benefits for global health and development. A healthy population is far more creative and productive, which bodes well for the future of international trade and investment. All countries will be more inclined to participate in the ideals of trade liberalization if they feel that the health and welfare of their people is a high priority.

Multiple issues sit at the intersection of these two realms, ranging from patented medicines and international commerce during public health emergencies to the migration of health workers. These critical issues, and many more, cannot be solved in isolation from trade and health and other overlapping regimes, such as environmental law and food security law, but require a coordinated approach at the national, regional, and international level. Just as there is an urgent need to incorporate more robust health protection in WTO agreements [54], so too would WHO treaties and global strategies and codes benefit from trade input. The siloed manner in which the WTO, WHO, and their respective member states have operated must evolve into mutual respect and collaboration.

Most importantly, the challenges facing the WTO require a marked shift in mentality. The WTO's and powerful states' pursuit of trade liberalization without sufficient concern for justice threatens to alienate key parties and drive members toward negotiations outside the WTO. This will only result in far worse outcomes for, and alienation of, developing countries, further undermining the development-themed Doha trade round. From a public health perspective, transparency, collaboration, and civil society engagement at the WTO are preferable to bilateral and regional FTA negotiations. "One Health, One World" requires that public health and global justice must remain at the forefront of WTO's agenda, while the WHO and other global health advocates must develop the political and economic power, as well as the expertise and mandate, to become a major force at the intersection of international trade and global health.

\section{International Environmental Law: Ameliorating the Hazards of Climate Change}

The core concern is succinctly stated: climate change endangers human health. The warming of the planet will be gradual, but the effects of extreme weather events - more storms, floods, droughts and heat waves - will be abrupt and acutely felt. Both trends can affect 
some of the most fundamental determinants of health: air, water, food, shelter and freedom from disease.

The environment and how people interact with it have always been central to the public's health, affecting hunger and famine, the nature and range of disease, and water-borne illnesses. Climate change exacerbates extreme weather events, threatens the water and food supply, increases climate-sensitive diseases, lowers air quality, and reduces biodiversity. Nearly one-quarter of the global disease burden is attributable to modifiable environmental factors [56]. The United Nations estimates that the global death toll from climate change could reach 500,000 annually by 2030 [57], with adaptation costs for the health sector in the range of \$4-12 billion [58].

Although climate change will affect everyone, it will disproportionately burden the global poor, deepening global health disparities [59]. The World Bank estimates that developing countries will bear $75-80 \%$ of the costs of climate change [60]. Even under a moderate scenario of a $2{ }^{\circ} \mathrm{C}$ warming, Africa and South Asia could experience a permanent decrease in GDP of 4-5\% [60]. Climate change will play a major role in placing Africa under severe water stress as early as 2020 [61]. Scarce sanitary water sources will significantly increase diarrheal disease, a leading cause of infant and child death in low-income countries.

Climate change will also exacerbate food insecurity, particularly in already drier, warmer parts of the planet, principally in the global south. If climate change is not halted, the length of the agricultural growing period in much of East Africa could be reduced by $20 \%$ by the end of the century [62]. This could significantly affect crop yields and domestic livestock. Additionally, climate change will have a deleterious impact on wild animals, birds, and fish — all of which are vital food sources for animals and humans. Increased competition for scarce resources could cause economic instability, mass migrations, civil unrest, and armed conflict [63,64].

Regional changes in temperatures and rainfall will shift the range of disease vectors such as mosquitoes, ticks, and rodents, bringing them in greater contact with humans [63]. Of particular concern is the effect of climate change on the geographic distribution of mosquitoes carrying malaria and dengue fever, the vector-borne illnesses with the greatest disease burden. As disease-carrying mosquitoes move to higher latitudes and altitudes, they will threaten human populations naïve to these diseases and therefore particularly vulnerable. Warm temperatures could also lead mosquitoes to proliferate even within their current range. In addition, food- and water-borne illnesses thrive in warmer conditions, and will likely increase [63].

The scarcity of clean water and nutritious foods, and high rates of infectious diseases that disadvantaged populations already face, will worsen. Furthermore, the world's poorest people contend with weak health systems, poor infrastructures, and less technological and manufacturing capabilities, undermining their ability to adapt to changing weather conditions.

Forests perform a wide range of ecological services that will be in ever greater demand in the face of global climate change: stabilizing local climate fluctuations, preventing droughts, protecting aquifers, preserving pollinator populations, stabilizing soil, and buffering population centers from storms and floods [65]. These services are critical to food security and to mitigating the death and 
disease associated with natural disasters. Deforestation increases the vulnerability of local populations in addition to its indirect impact on global health through climate change [66].

Tropical forests have great potential to provide new medicines. Currently, 50,000-70,000 modern and traditional medicines are derived from plant species, with more than half of medicines in the past quarter-century being derived or modeled after compounds from other species [67]. Beyond this, biodiversity plays a crucial role in human nutrition through its influence on world food production, as it ensures the sustainable productivity of soils and provides the genetic resources for all crops, livestock, and marine species harvest for food [68]. Patterns of infectious disease also are sensitive to disturbances of the structure and function of ecosystems and the resulting loss of biodiversity.

\subsection{Environmental Law Treaties: Unfulfilled Promises and Expectations}

To ameliorate the profound effects of climate change on people and the natural environments in which they live, the international community has adopted several key treaties. The 1985 Vienna Convention for the Protection of the Ozone Layer (Vienna Convention) and its 1987 Montreal Protocol is the oldest and most successful environmental treaty. The United Nations Framework Convention on Climate Change (UNFCC) and its Kyoto Protocol is perhaps the most contested. Finally, the 1992 Convention on Biological Diversity aims to protect forests and biodiversity.

\subsubsection{The Vienna Convention and the Montreal Protocol}

The Vienna Convention, a framework-protocol approach, sets out principles, processes, and institutions to reduce emissions of ozone-depleting substances [69]. The 1987 Montreal Protocol creates specific obligations to reduce certain ozone-depleting substances, including a timetable to phase out the production and use of ozone-depleting chemicals and creating a multi-lateral fund to assist developing countries [69].

In a historic achievement, all UN members have ratified the Vienna Convention and the Montreal Protocol, and compliance has been high. International cooperation has led to a dramatic deceleration of ozone depletion caused primarily by chlorofluorocarbons used in refrigeration. Scientists expect a substantial recovery of the ozone by the mid-21st century [70].

Seeking to emulate this success, political leaders have sought to use the framework-protocol approach to address climate change. However, the complexity, the enormity of impact, and the level of investments required have thwarted progress. Climate change is pivotal to the global economy and energy. Unlike ozone-depleting chemicals, substitutes for the harmful pollutants and the human activities releasing them are less immediately available at sufficient scale and competitive cost $[71,72]$.

\subsubsection{UN Framework Convention on Climate Change and the Kyoto Protocol}

The UNFCCC, with its Kyoto Protocol, is the main international treaty addressing climate change. The UNFCCC came into force in 1994 and, by 2012, 194 states and the EU had ratified [73]. Providing a broad framework, the UNFCCC aims to stabilize greenhouse gas concentrations at a level that would prevent dangerous anthropogenic harms within a timeframe to allow ecosystems to adapt naturally, protecting food production and economic development. The Convention embraces a 
two-pronged policy approach: mitigating climate change by reducing atmospheric greenhouse gas concentrations and adapting human systems to handle the adverse effects.

Originally, the Convention sought to stabilize the greenhouse gas emissions of industrialized countries at 1990 levels by the year 2000. In 1997, state parties negotiated the Kyoto Protocol, which came into force in 2005. Thirty-seven developed countries and the European community agreed to reduce emissions to at least 5\% below 1990 levels by 2012, but without binding targets. The Protocol created an emission trading system, with joint implementation and cooperation between developed and developing countries.

States have fallen far short in meeting their obligations. The United States, the largest greenhouse gas emitter until surpassed by China in 2010, failed to ratify the Protocol. With the Kyoto Protocol expiring in 2012, a successor is needed. The Intergovernmental Panel on Climate Change (IPCC) recommended that industrialized countries commit to $25-40 \%$ emission reductions by 2020 compared to 1990 levels, thus avoiding a $>2$ degrees Celsius rise in average temperatures.

Negotiating a successor to the Kyoto Protocol has proved politically challenging. The Copenhagen Accord, negotiated during the $15^{\text {th }}$ session of the Conference of Parties (COP 15) in December 2009 called for transparency, verification, and $\$ 100$ billion annually by 2020 to assist developing countries. Key states negotiated the voluntary Copenhagen Accord (US, Brazil, China, India, and South Africa), but it lacked legitimacy by omitting low-income countries. The December 2011 COP 17 in Durban, however, resolved for the first time to negotiate a binding treaty to succeed the UNCCC by 2015, coming into force after 2020.

The UNFCCC requires states parties to "facilitate adequate adaptation to climate change" and to assist developing countries "in meeting costs of adaptation" (Art. 4). Financial and technical assistance for adaptation is closely tied to mitigation: developing countries' willingness to commit to mitigation depends on substantial funding for adaptation [74].

The Kyoto Protocol Adaptation Fund, negotiated in 2006, proposed a 2\% tax levied on private emission-offset projects undertaken in developing countries. This innovative mechanism has the potential to create an adaptation budget five times greater than the two earlier climate change funds, which relied on voluntary donations [75]. However, adaptation funding remains grossly insufficient, with poor countries lacking capacity. COP 17 pledged to create a "Green Climate Fund" to mobilize the promised $\$ 100$ billion a year by 2020 to assist poor countries to adapt to climate change and convert to clean energy sources.

\subsubsection{Convention on Biological Diversity}

The1992 Convention on Biological Diversity (CBD) governs deforestation, which has a sharp edge because richer states and pharmaceutical companies want access to biologically diverse genetic resources in tropical forests. Developing countries, however, express concern with "biopiracy" - taking genetically valuable resources and patenting scientific discoveries without sharing the profit with the host country.

The CBD aims to protect biodiversity while facilitating cooperation in scientific and technical endeavors. Although the treaty emphasizes sovereignty over biodiversity within states' territories, bitter controversies have erupted when pharmaceutical companies aggressively pursue intellectual 
property rights. A clash between the CBD (asserting state sovereignty) and the TRIPS Agreement (asserting property rights) has slowed progress on protecting biodiversity [76].

\subsection{The Role of Health in International Environmental Law}

The UNFCCC, despite its undoubted value to health [77], rarely invokes population health, but simply acknowledges "deleterious effects ... on human health and welfare [78]". It also commits states parties to minimize the adverse effects on the economy, public health, and the environment [78].

Sadly, health advocates were not actively engaged in the UNFCCC negotiations. The U.S. delegation to the 2009 Copenhagen Summit, for example, did not include the health secretary or congressional health committee members $[79,80]$. Without a strong voice for health, climate change law has not embraced innovative ideas for human wellbeing. There are tentative signs of progress, such as adoption of climate change resolutions by the World Health Assembly [81] and WHO's recent partnership with the UN Environment Program through the Health Environment Linkages Initiative (HELI) [82].

Despite the significant interplay between health and climate change, advocates still largely operate on separate tracks. Applying the principles of "One Health, One World" health advocates in wealthier countries, which should bear much of climate change mitigation and adaptation costs, should remind policymakers of the tremendous health effects of populations in their own country. The heat wave as severe as the one that struck Europe in 2003, leading to 35-70,000 deaths, could represent an average summer by 2040 [83-85]. The loss of biodiversity, of which climate change is one culprit, will slow the discovery of new medicines important globally including in wealthy nations. Of the 150 most widely subscribed drugs in the United States, 57\% are derived from plants, animals, or microorganisms [86].

The United Nations charged the WHO with better integration of health and the environment [87], with Ban Ki-Moon calling climate change and development the key global health priorities [88]. The MDGs, moreover, identify health, development, and the environment as interconnected human needs. Global health organizations, notably the WHO, must advocate strongly for increased attention to population health in environmental governance.

Building capacity in low and middle-income countries for adaptation to climate change must become a high priority. For example, the planned $\$ 100$ billion Green Climate Fund should be devoted to reducing the profound health impacts of climate change. Funds should flow to local communities and national governments for preventing and controlling infectious diseases, preparing for extreme weather events, and increasing the supply of clean water for drinking and fresh water for agriculture. The Kyoto Protocol should include targets and benchmarks not only for reducing greenhouse gas emissions, but also for mitigating health impacts, accompanied by international cooperation to ensure that poor countries have the financial and technical capacity to implement such measures.

Given that most health impacts come from domestic rather than transboundary pollution, international environmental law should also impose duties on governments to their own people similar to those imposed under human rights and labor law. Consider indoor air pollution, responsible for nearly 2 million deaths per year, with cooking using solid biofuels such as wood, dung, and coal being the primary culprit. "One Health, One World" requires that international treaties create state obligations, supported through international assistance and cooperation, to enable their people to use 
cleaner and healthier forms of energy. [89,90]. For example, the UN Millennium Project had proposed incorporating this target into the Millennium Development Goals: "By 2015, to reduce the number of people without effective access to modern cooking fuels by $50 \%$, and make improved cooking stoves widely available." [91].

\section{Food Security: Eliminating Hunger and Ensuring Access to Food}

For hunger is a direct affront not only to the physical integrity but also to the very dignity of the human person. Hunger is an insult to the fundamental values of the international community. And we are well aware that a society would be doomed to shame and dishonour if, at the end of the twentieth century, there persisted what [Pope John Paul 11] has so appropriately called 'the structures of famine.'

H.E. Boutros Boutros-Ghali, 1996 [92]

As the crisis in the Horn of Africa demonstrates, food insecurity is seldom caused by insufficient food alone, but rather entails political and economic choices. Economist Abhijit Banergee observes, "We live in a world that is capable of feeding every person that lives on the planet. The world produces twice as much food than needed for the world's population. But, valuable land is used for biofuels, food is thrown out and wasted, and farmers grow food outside population centers and price it beyond the reach of the poor."

Governments increase malnutrition by incentivizing farmers to grow plants for fuel instead of food; subsidizing unhealthy foods such as corn for high fructose syrup; or paying them not to grow crops at all, leaving fertile land vacant. At the same time, agricultural subsidies in Europe and North America unfairly disadvantage local farmers in Africa and other poor regions.

Food insecurity remains perhaps the most troubling health crisis of our time. The number of undernourished people - 25 million in 2010 - is higher than in 1996 when the World Food Summit promised to halve the number of undernourished people by 2015 [93]. Millennium Development Goal 1 also aims to halve the proportion of people who suffer from hunger between 1990 and 2015, but is not meeting its targets. Undernourishment contributes to $56 \%$ of child deaths in developing countries [94], also causing growth retardation and impaired development [95,96]. Undernourishment during pregnancy can lead to low-birth weight and poor health throughout the lifespan [97].

Insufficient micronutrients remain an enduring problem even among people who consume enough calories. Half of all women of childbearing age in poor countries have iron-deficient anemia, and more than half a million children develop vitamin A-deficient blindness. Half of those children die within a year of going blind. Approximately 400,000 people die each year due to insufficient zinc. Paradoxically, many poor people suffer the dual burden of obesity and malnutrition by consuming excessive quantities of low-nutrient foods.

\subsection{Overlapping Problems and Regimes in Food Security}

The Universal Declaration of Human Rights declared a right to food as early as 1948. The International Covenant on Economic, Social and Cultural Rights (ICESCR) requires states parties to 
"recognize the right of everyone to an adequate standard of living ... including adequate food." The ICESCR imposes both a global and domestic responsibility (Art. 11(2)):

Recognizing the fundamental right of everyone to be free from hunger, [state parties] shall take, individually and through international cooperation, measures ... to ensure an equitable distribution of world food supplies in relation to need.

The Rome Declaration on World Food Security and World Food Summit Plan of Action reaffirmed "the right of everyone to have access to safe and nutritious food". "Food should not be used as an instrument for political and economic pressure." Although these instruments are non-binding, General Comment 12 on the Right to Adequate Food - an interpretive instrument for the ICESCR - incorporates their core content, affirming the right to "food in a quantity and quality sufficient to satisfy the dietary needs of individuals, free from adverse substances, and acceptable within a given culture".

The Committee on World Food Security (CFS), established in 1974, aims to be "the most inclusive international and intergovernmental platform for all stakeholders to work together to ensure food security and nutrition for all". The CFS' goals include coordinating a global approach to food security through policy convergence, providing supporting and advice to countries, and developing a global strategic framework for food security and nutrition.

\subsubsection{Food Security and Trade}

The Plan of Action recognizes the importance of trade to food security, stating, "We will strive to ensure that food, agricultural trade and overall trade policies are conducive to fostering food security for all through a fair and market-oriented world trade system [98]”. Yet, trade policies, financial markets, and higher energy costs have increased food prices and decreased disposable income. Due, in part, to market forces, the poor spend increasing larger proportions of their income on food.

Three major drivers are rapidly increasing the rise in real food prices [99]. First, emerging economies are increasing the demand for food and shifting preferences from cereals to meat. Second, demand for biofuels produced from maize is increasing due to high-energy costs and government policies. Finally, increased transportation and fertilizer costs are increasing the cost of food and decreasing food production [99]. These drivers of rising costs vividly illustrate the interconnections between globalization, energy, food, and human health.

The WTO's Agreement on Agriculture sought to establish “a fair and market-oriented agricultural trading system" by progressively reducing agricultural supports and protections, such as agricultural and export subsidies [100]. Concerned about the Agreement's negative effects on developing and net-food importing countries, the Uruguay Round developed the Marrakesh Ministerial Decision to increase food aid "sufficient to meet the legitimate needs of developing countries." Sadly, implementation of the Marrakesh Decision has been weak leading, in part, to the Doha WTO Ministerial Conference [101]. Food prices are still rising, aid is inadequate, and agricultural subsidies in North America and Europe continue to place developing world farmers at a trade disadvantage. 


\subsubsection{The Role of Food Aid}

By definition, a state that requires food aid is not food secure. Nevertheless food aid is essential in alleviating malnutrition and hunger in times of crisis. Unfortunately, bilateral food aid can be more about the donor's interests than the needs of the poor, such as by sending the donor's surplus food rather than meeting local needs, or by shipping food long distances rather than buying locally.

The FAO's World Food Program (WFP), established in 1963, now accounts for an increasing share of world food aid. The WFP has pushed for food security promotion, using local purchases. The WFP purchases surplus food in one area of a recipient country to distribute to other areas in need. Despite its appeal, however, WFP food aid is inherently limited by insufficient food in low-income countries. Further, a decrease in donor country surplus crops has led to an overall decrease in global food aid. Consequently, assistance is increasingly reserved for emergencies, such as famines, conflicts, and mass migrations [102]. And even here, food relief is often too little and too late, as occurred in Malawi (2001/02) and Niger (2004/05) [103]. What is most important is to prevent the conditions leading to food emergencies, while managing food supplies over the long-term [104].

The Food Aid Convention 1999 calls for multilateral cooperation for both long-term aid, as well as emergency relief. State parties pledged specified minimum amounts of grains and other eligible products, such as edible oil, skimmed milk powder, and seeds to developing countries, irrespective of fluctuations in world food prices and supplies [105]. But rich countries have not lived up to their promises.

\subsection{Expanding the Scope of Food Security Law}

Given the significance of food security not only to health but also to political stability, this body of international law is remarkably slim, with even the Food Aid Convention highly limited in scope. "One Health, One World" requires that the international community establish new norms and forms of accountability to secure adequate food and nutrition for the world's growing population, and particularly for its most vulnerable members. A new treaty, for example, could build on the Food Aid Convention by prioritizing local food supplies purchases, while expanding funding for the UN Central Emergency Response Fund to ensure a timely response to humanitarian crises 106. The Central Emergency Relief Fund, established in 2006, seeks up to \$500 million annually, though pledges have yet to reach this mark [107]. Oxfam, which had advocated for such a fund, had called for a fund at least twice this size [108].

Beyond assistance, a food security treaty could address present and potential threats to hunger and malnutrition. It could require countries to prioritize food production over biofuels that take up precious agricultural land, ensure funding for research into more nutritious and sturdy crops, and regulate "land grabs"- the large-scale foreign purchase of land that threatens food security [109].

Meanwhile, beneficiaries of international support could commit themselves to policies that enhance food production, ensure food assistance is not diverted to the military or elites, ensure transparency, and permit monitoring of food assistance. States should seek international assistance when their populations are in need instead of denying the existence of hunger to the detriment to their people. 


\section{International Humanitarian Law: Protecting Health in Times of War}

From a strictly legal standpoint a veritable law of humanity has been created, whereby the integrity and dignity of the individual are protected in the name of a moral principle that transcends the boundaries of national law or politics.

Max Huber, undated [110]

All armed conflicts take a terrible toll on soldiers and civilians, resulting in countless injuries, disabilities, and deaths [111]. The WHO predicts that by 2020 armed conflict will be among the leading causes of death for 17-44 year olds [112]. Beyond the tragic health consequences of gunfire, aerial bombardment, and other munitions, affected communities often struggle to maintain adequate food, water, health services, and sanitation. During the 2011 Libyan conflict, for example, hospitals in Tripoli not only were unable to care for the wounded, but also ran out of medications to treat chronic diseases, such as diabetes and cancer [113]. During the 1991 Persian Gulf War, 50-70\% of the Iraqi's killed were civilians, with 700,000 deaths resulting from the destruction of medical facilities, water supplies, and electric power plants. The effects of armed conflict is particularly devastating in the world's least healthy states, such as the Democratic Republic of Congo and Somalia, in which most modern warfare has taken place.

To remedy the worst excesses of armed conflict, states have developed a body of International Humanitarian Law (IHL) - the law of war or of armed conflict — comprising the Hague Conventions of 1899, the four Geneva Conventions of 1949, disarmament treaties, and customary laws. State parties are obliged to prevent and put an end to IHL violations, as well as to punish those responsible for "grave breaches" of war crimes. Although IHL creates binding norms, they are often ignored, even flouted. Forces driving hostilities undermine the rule of law, such as when ethnic divides make antagonists view each other as less than human; or when authoritarian leaders feel their very survival is at stake.

\subsection{The Effects of Armed Conflict on Public Health}

Armed conflict vastly diminishes the supply of and access to critical health resources, such as medicines, medical equipment, and hospitals [114]. During the 1992 Bosnian war, for example, child mortality nearly doubled while newly diagnosed cases of tuberculosis quadrupled [115]. In extended conflicts public health programs, such as immunizations and disease surveillance systems may be drastically reduced or even halted [114]. Indeed, in modern warfare an enemy's infrastructure, rather than combatants, is often the primary target. Despite the Hague and Geneva Conventions, which prohibit directly targeting civilians, the proportion of civilians dying in armed conflict has increased from $67 \%$ in World War II to $90 \%$ today [116].

Medical personnel and facilities are also often targeted, particularly in intrastate conflicts. In 2011, the Bahraini government dampened protests by attacking medical facilities, health personnel, and patients. Security forces physically beat doctors and nurses trying to provide care to wounded protesters. They took over hospitals, forcibly removed patients, and blocked ambulances from reaching the wounded [117]. 
Health impacts, moreover, endure long after the end of armed conflict. Conflict damages health infrastructure, increases poverty, and disrupts education. The 1999 NATO bombing in Serbia destroyed 147 health facilities as well as 66 bridges, 78 factories, and 200 schools. The wars in Iraq and Afghanistan destroyed the electricity supply, preventing the purification of drinking water [118]. Infectious diseases such as malaria, cholera, and tuberculosis remain high long after active warfare ends [119]. Children suffer from vast increases in diarrheal disease, while women lose access to obstetrical care [120].

Armed conflict destroys natural resources, devastates native habitats, disrupts regional cooperation, and pollutes the air and water. During the Vietnam War, the US bulldozed large tracts of forests and farmland, dropped 13 million tons of bombs, sprayed 72 million liters of herbicides such as Agent Orange, and used napalm to burn forests in the Mekong delta [121]. Cancer-causing weapons such as uranium are also used indiscriminately. For example, nearly $40 \%$ of Chechen territory was contaminated by radioactive waste during the late 20th century conflict [122].

\subsection{Origins and Content of Humanitarian Law}

International humanitarian law defines the rights and obligations of antagonists, safeguarding civilians, the sick and wounded, and prisoners [123]. Modern IHL is rooted in the efforts of Swiss Businessman, Henry Dunant, who mobilized townspeople to care for the wounded in the French/Austrian battle in Solferino, Italy. In 1862, Dunant proposed a relief agency for humanitarian aid, which became the International Committee of the Red Cross (IRC) formed in 1864. He also proposed an international treaty affirming the agency's neutrality and freedom to offer aid, which became the First Geneva Convention that was ratified by 14 countries in 1864 [124].

The Geneva Conventions provide the rules of war, aimed at protecting non-combatants from the destructive impact of battle. Collectively covering both international and internal conflicts, the four Conventions require care for wounded and sick soldiers and extend an array of protections to prisoners of war, whose physical and mental health should not deteriorate during captivity. They demand protection for medical personnel and infrastructure. And with perhaps the greatest potential to limit disease, death, and destruction of war, the Conventions prohibit the deliberate destruction of "objects indispensable to the survival of the civilian population, such as foodstuffs, crops, livestock, drinking water and supplies" (Fourth Geneva Convention, art. 54), and establish such principles as military necessity and proportionality to protect civilians. All UN members have ratified the Geneva Conventions, though its Protocols have yet to receive universal acceptance $[125,126]$.

Although most of the Conventions' terms apply only to international conflict, all four Conventions provide certain safeguards during domestic disputes. The Conventions require states to prosecute fundamental violations during international disputes. The Security Council can establish tribunals to prosecute violations during domestic disputes, such as the International Tribunal for Rwanda.

The IRC is uniquely mandated to "protect the lives and dignity of victims of armed conflict ... to provide them with assistance ... [and] to prevent suffering by promoting and strengthening humanitarian law and universal humanitarian principles [127]”. The three distinctive emblems of the IRC - the red cross, red crescent and red crystal-identify and protect medical and relief workers as well as medical facilities. 
Although sanctions are a primary method of enforcing IHL, the international response has ranged from forcefully protecting civilians in Libya and war crime investigations in the DRC and Sri Lanka, to sanctions, indictments, and a UN peacekeeping force in Sudan. Yet, IHL accountability has been limited. Enforcing IHL against non-state actors, such as rebel groups, is particularly challenging because they are less susceptible to diplomatic pressure or sanctions, and often act outside the rule of law.

\subsection{Strengthening International Humanitarian Law: Enforcement and Expansion}

Public health advocates often focus on naturally occurring injury and disease, neglecting the dire health effects of war. Following the "One World, One Health" approach, health professions can provide expertise on preventing, monitoring, and ameliorating harms in times of conflict. They can advocate for stricter accountability and enforcement of IHL norms. Finally, following the they can show the intersections between violence and multiple health consequences relating, for example, to food security, mass migrations, and the rights of women and children.

Greater compliance with existing IHL is of paramount importance in protecting the public's health. Beyond stepped up education, ensuring that combatants understand their legal obligations, the law itself could be used to improve adherence. Currently, sanctions can be imposed only through affirmative Security Council action. But it should be possible to impose a tailored set of sanctions automatically when an independent entity finds a serious breach of IHL. This approach might include safe harbors and processes states could take to avoid automatic sanctions, such as IHL training and national disciplinary procedures.

Health advocates could also build upon recent treaties targeting weapons that indiscriminately harm civilians, such as land mines and cluster munitions. Small arms, for example, are a true instrument of mass destruction [128], given their role in killing three-quarters of a million people annually, including 400,000 homicides $[129,130]$. The UN Program of Action on small arms and light weapons addresses illicit trade, but is non-binding and poorly implemented [131-133]. Health advocates should join other movements insisting on adherence to the Program of Action, as well as codifying its provisions. The Campaign to Ban Landmines which drove the process that culminated in a treaty banning this indiscriminate weapon is useful model for civil society engagement.

The more traditional body of international law, the Geneva Conventions, also could be strengthened. The Conventions, for example, could ensure that public health infrastructure destroyed in war is quickly rebuilt. As a further deterrence against infrastructure destruction, the Conventions could create a legal obligation on the responsible party to fund reconstruction.

\section{Forced Migration: The Laws Protecting Refugees and Other Displaced Persons}

Many prosperous countries with strong economies complain about the large number of asylum seekers, but offer too little to prevent refugee crises, like investing in conflict prevention, return, reintegration. 
Inadequate housing, crowded living conditions, and poor sanitation threaten the health of refugees and internally displaced persons. Infectious diseases, often exacerbated by malnutrition, can spread quickly in refugee camps. Measles outbreaks resulted in large numbers of deaths in camps in Somalia, Bangladesh, Sudan, and Ethiopia [135]. In the wake of natural disasters, internally displaced people similarly suffer devastating health problems. Following the 2010 earthquake in Haiti, for example, nearly 6,000 people died from cholera [136]. In the immediate aftermath of Hurricane Katrina in 2005, aid workers struggled to find medications to treat chronic diseases [137].

Refugees often spend months, sometimes years, in refugee camps. Children born in the camps may grow up there. Over two-thirds of the refugees live in "protracted refugee situations." Although refugee camps can efficiently provide aid to large numbers of people in emergency situations, they are susceptible to disease outbreaks, endemic brutality including rape and domestic violence, and enforced idleness and dependency. Refugees in Dadaab, Kenya, for example, must survive on gruel that becomes thin by the end of the month [138].

In contrast, rather than living in camps, Iraqi refugees in Syria, Lebanon and Jordan have "self-settled," living in local communities, some able to work legally while others work in the informal economy. UNHCR provides refugees cash assistance and refurbished health clinics, helping both refugees and the communities in which they live [139]. Self-settlement can protect refugee health with sanitation, clean water, vector control, and law enforcement. However, self-settlement can overburden the health services and infrastructure of host countries. Kenya, for example, hosts over half a million Somali refugees, which would be the equivalent to the United States hosting 3.75 million refugees [138]. International assistance is, therefore, essential to the success of self-settlement.

International law could help by safeguarding the rights of refugees and other displaced persons, as well as apportioning the costs of meeting their health and social needs. Without an effective international regime, the critical needs of refugees and other displaced persons will continue to go unmet as the poorest countries continue to disproportionately bear the burdens.

Originally intended only to only address refugees displaced in Europe during World War II, refugee law currently requires states parties to the 1951 Refugee Convention Relating to the Status of Refugees and 1967 Protocol (1951 Refugee Convention) to protect individuals who were forced to flee their home countries "owing to a well-founded fear of being persecuted for reasons of race, religion, nationality, membership of a particular social group, or political opinion." State parties must also cooperate with the UN High Commissioner in protecting, assisting, and finding a solution for refugees [140]. The 1951 Refugee Convention prohibits refoulment or the forced return of refugees [140]. UNHCR may intervene to keep refugees from being returned to a place where they would face persecution

Under the 1951 Refugee Convention, as well as customary law, host countries must guarantee refugees many of the rights afforded to nationals, including access to public relief and assistance. In addition, the ICESCR guarantees the right to health for all persons, including refugees. General Comment 14 asks states to refrain from "denying or limiting equal access for all persons, including prisoners or detainees, minorities, asylum seekers and illegal immigrants to preventive, curative and palliative health services [141]".

Refugees are also protected by regional conventions, which have adopted broader definitions of refugee status. The widespread population displacements resulting from the conflicts that accompanied 
the end of the colonial area in Africa precipitated the 1969 Organization of African Unity Convention Governing the Specific Aspects of Refugee Problems in Africa (OAU Refugee Convention). Because the OAU Refugee Convention adopted an objective standard for defining refugees, persons fleeing widespread violence, civil disturbances and war are entitled to protection even if they do not have a well-founded fear of persecution, as is required by the 1951 Refugee Convention [142].

The Cartagena Declaration, adopted by Latin American experts and government representatives in 1984, expands the definition of refugees to include persons who have fled their countries because of generalized violence and other circumstances that have seriously disturbed the public order. Although not legally binding, at least 13 Latin American States use the definition, which has also been endorsed by the Organization of American States, the UN General Assembly, and the UNHCR [142].

The 1990 Convention on the Protection of the Rights of All Migrant Workers and Members of their Families (MWC) guarantees emergency medical treatment for all migrant workers and their families -i.e., "medical care that is urgently required for the preservation of their life or the avoidance of irreparable harm to their health on the basis of equality of treatment with nationals". Despite its potential to protect a broader group of migrants, the MWC has been ratified by only 45 states and signed by an additional 14 states $[143,144]$. Neither the United States nor any European Union member has signed the convention.

The 1954 Convention Relating to the Status of Stateless Persons protects individuals who are not nationals of any state. The 1961 Convention on the Reduction of Statelessness affords stateless persons a pathway to nationality if they have an appropriate link with the state through birth or descent. Article 23 requires states to provide the same public relief and assistance to stateless persons as provided to the states' nationals. Article 24 similarly requires that stateless persons be provided the same social security benefits, including maternity, sickness and disability benefits as provided to nationals. In 1974, the General Assembly charged UNHCR with supervising claims under the 1961 Convention [145].

Refugee law does not cover internally displaced persons who are forced from their homes but have not crossed an international border. Internal displacement is a major humanitarian crisis, with some 27 million IDPs in 22 countries [146]. In the 1990's, relief organizations, including UNHCR and the UN Children's Fund (UNICEF), requested [147]. In response, the 1998 Guiding Principles on Internal Displacement (Guiding Principles) were developed, describing the rights of, and obligations to, IDPs.

Although not legally binding, the Guiding Principles are an important source of standards that have been incorporated into domestic law in a number of states with significant internally displaced persons. The Guiding Principles specify that IDP have the right to an adequate standard of living including "essential medical services" and "to the extent practicable" should receive necessary medical care, including psychological services. The Guiding Principles also note that special attention should be paid to women's health needs, including reproductive care [148]. In 2005, the General Assembly recognized the Guiding Principles as "an important international framework for the protection of internally displaced persons [149]". The Guiding Principles "restate existing human rights and humanitarian law and apply refugee law by analogy [150]".

In October 2009, the African Union (AU) adopted the African Union Convention for the Protection and Assistance of Internally Displaced Persons (the Kampala Convention), which is the only internal displacement-specific convention covering an entire continent and builds upon the Guiding Principles. 
The Kampala Convention requires that states parties provide adequate medical care and other health services to IDPs to the "fullest extent practicable" [151].

Global health advocates must work to ensure that health remains a priority as the law of forced migration continues to develop and expand beyond refugees. Following the principles of "One Health, One World" international law concerning forced migration must incorporate innovative solutions to address and protect the health of all displaced persons. The focus must shift away from refugee camps and towards self-settlement to improve the health of displaced people and the communities in which they settle. The global community must provide support to countries in which displaced persons settle so that the burden of forced migration is shared.

\section{Conclusion}

In 1952, a "killer smog" settled over London, causing thousands of deaths and sparking comprehensive regulation, as well as the first international air pollution conference [152-154]. Public health advocates were at the forefront in curbing air pollution. The 2011 public health crisis in the Horn of Africa could similarly provide the impetus for health advocates to effectively use international law in multiple fields. For that to happen, global health actors - together with civil society partners -need to develop the expertise and influence to ensure that human health is not sacrificed to other concerns, such as trade, agriculture, or geostrategic interests.

It is time for international law to catch up with global reality. Despite the synergies between trade, climate change, food, mass migrations, and armed conflict, the international community lacks the vision to see how these legal regimes could work together for the global common good-a classical formula of "One World, One Health". Steps are already being taken to move in this direction. For example, in January 2011 the report of the United Nations Secretary-General's High Level Panel on Global Sustainability, aptly titled, Resilient People, Resilient Planet: A Future Worth Choosing," called for a long-term vision "to eradicate poverty, reduce inequality and make growth inclusive, and production and consumption more sustainable, while combating climate change," and recognized the multiple intersections between different areas of law and the effect of those areas on global development, health and the environment [155]. Momentum is building for an interconnected approach to global health.

To capitalize on this momentum global health scholars and advocates cannot simply focus on the health sector. Nor can they limit their work to scientific and technological improvement. To make dramatic progress, advocates will have to effectively use international law. And they will have to realize that food, trade, human rights, humanitarian relief, and the environment are critically important in improving health and reducing health inequalities.

International health law focuses principally on health security and particular diseases such as tobacco. But international law can do much more by focusing on the cumulative effects of policies from multiple legal sectors including trade, the environment, food security, humanitarian crises, and the plight of refugees. To make dramatic progress in global health, scholars and advocates will have to effectively use international law. And they will have to realize that food, trade, human rights, humanitarian relief, and the environment are critically important in improving health and reducing health inequalities. The "One Health, One World" idea demands that global actors break down the 
silos and embrace a unified vision of healthy, well nourished, and safe human and animal populations living together in a clean and sustainable environment.

\section{Acknowledgments}

The authors would like to thank Eric A. Friedman and Bryan P. Thomas for their invaluable comments on multiple drafts of this article. We would also like to thank Thandiwe Lyle and Sarah Stewart for their research assistance.

\section{References and Notes}

1. Töpfer, K. Speech delivered at the adoption of the Judges' Johannesburg Principles on the Role of Law and Sustainable Development, Johannesburg, South Africa, August 2002.

2. Nabarro, D. One world, one health. The Links between animal and human health are clearly emerging. IAEA Bull. 2009, 51-1, 27-31; Available online: http://www.iaea.org/Publications/ Magazines/Bulletin/Bull511/51105532731.html (accessed on 20 February 2012).

3. US Centers for Disease Control and Prevention. One Health. Available online: http://www.cdc.gov/onehealth/ (accessed on 20 February 2012), Reflecting the interconnectedness of health and ecology.

4. Resilient People, Resilient Planet: A Future worth Choosing; The report of the United Nations Secretary-General's High-level Panel on Global Sustainability; United Nations: New York, NY, USA, 2012. Available online: http://bit.ly/A53RPs (accessed on 20 February 2012).

5. Gettleman, J. Food Crisis in Somalia is a Famine, U.N. Says. New York Times, July 20, 2011, p. A9.

6. Walk of Horror: Hungry Somalis Endure Death in Weeks-long Walk to Find Food at Camps. Washington Post, July 11, 2011.

7. Dixon, R. Militia in Somalia bars food aid, rights group says. Los Angeles Times Los Angeles, CA, USA, August 16, 2011.

8. Gettleman, J. Somalis Waste Away as Insurgents Block Escape from Famine. New York Times New York, NY, USA, August 1, 2011, p. A1.

9. Heinlein, P. US Official Decries Slow Progress Reducing Somalia's Child Mortality Rates. Voice of America Washington, DC, USA, September 1, 2011.

10. Somalis face hunger and fear in Kenya's refugee camps. Guardian London, UK, July 24, 2011.

11. Cholera claims 195 more lives in Somalia. PressTV Tehran, October 16, 2011.

12. Labonte, R.; Sanger, M. Glossary of the world trade organization and public health: Part 1. J. Epidemiol. Community Health 2006, 60, 655-661.

13. Smith, R.D. Trade and public health: Facing the challenges of globalization. J. Epidemiol. Community Health 2006, 60, 650-651.

14. United Nations. Resilient People, Resilient Planet: A Future Worth Choosing Press Release; United Nations: New York, NY, USA, 2012. Available online: http://www.un.org/gsp/report (accessed on 20 February 2012). 
15. Moore, M. The Case for the 'Open Society' and the Role the WTO Plays. Address to the Australia-Israel Chamber of Commerce, Adelaide, Australia, 2 February 2001. Available online: http://www.wto.org/english/news_e/spmm_e/spmm51_e.htm (accessed on 2 June 2011).

16. Blouin, C.; Drager, N.; Smith, R. International Trade in Health Services and the GATS; The World Bank: Washington, DC, USA, 2006.

17. WHO; WTO. WTO Agreements and Public Health: A Joint Study by the WHO and WTO Secretariat; WTO Secretariat: Geneva, Switzerland, 2002. Available online: http://www.wto.org/english/res_e/booksp_e/who_wto_e.pdf (accessed on 20 February 2012).

18. Bloche, M.G.; Jungman, E.R. Health policy and the WTO. J. Law Med. Ethics 2003, 31, 529-545.

19. Bettcher, D.; Yach, D.; Guindon, G.E. Global trade and health: Key linkages and future challenges. Bull. WHO 2000, 78, 521-534.

20. Labonte, R.; Sanger, M. Glossary on the world trade organisation and public health: Part 2. J. Epidemiol. Community Health 2006, 60, 738-744.

21. Understanding the WTO Agreement on Sanitary and Phytosanitary Measures. WTO: Geneva, Switzerland, 1998. Available online: http://www.wto.org/english/tratop_e/sps_e/spsund_e.htm (accessed on 6 June 2011).

22. Baldwin, R.E. Multilateralising regionalism: Spaghetti bowls as building blocs on the path to global free trade. World Econ. 2006, 29, 1451-1518.

23. Marrakesh Agreement Establishing the World Trade Organization (1994). Entered into Force 1 January 1995; 1867 U.N.T.S. 410; art. 5.

24. International Intergovernmental Organizations Granted Observer Status to WTO Bodies. WTO: Geneva, Switzerland, 2012. Available online: http://www.wto.org/english/thewto_e/ igo_obs_e.htm (accessed on 6 June 2011).

25. Guidelines for Arrangements on Relations with Non-Governmental Organizations. WTO: Geneva, Switzerland, 2012. Available online: http://www.wto.org/english/forums_e/ ngo_e/guide_e.htm (accessed on 6 June 2011).

26. Scholte, J.A.; O’Brien, R.; Williams, M. The WTO and civil society. J. World Trade 1999, 33, $107-124$.

27. Relations with Non-Governmental Organizations/Civil Society. WTO: Geneva, Switzerland, 2012. Available online: http://www.wto.org/english/forums_e/ngo_e/intro_e.htm (accessed on 6 June 2011).

28. Jackson, J.H. World Trade Organization: Constitution and Jurisprudence; Chatham House, The Royal Institute of International Affairs: London, UK, 1998; p. 22.

29. Thailand - Restrictions on Importation of and Internal Taxes on Cigarettes; Panel Report. BISD 37S/200, November 7, 1990.

30. Epps, T. International Trade and Health Protection: A Critical Assessment of the WTO's SPS Agreement; Edward Elgar Publishing: Cheltenham, UK, 2008; p. 205.

31. Agreement on Technical Barriers to Trade (TBT Agreement) (1994). Entered into Force 1 January 1995; art. 2.2.

32. WHO Framework Convention on Tobacco Control; WTO: Geneva, Switzerland, 2003. Available online: http://whqlibdoc.who.int/publications/2003/9241591013.pdf (accessed on 13 March 2012). 
33. Eckhardt, J. Balancing interests in free trade and health: How the WHO's framework convention on tobacco control can withstand WTO scrutiny. Duke J. Const. Law Public Policy 2002, 197-230.

34. Campaign for Tobacco-Free Kids. Public Health, International Trade and the Framework Convention on Tobacco Control; Campaign for Tobacco-Free Kids: Washington, DC, USA, 2001; p. 15.

35. Zarrilli, S. WTO sanitary and phytosanitary agreement: Issues for developing countries. In Trade-Related Development and Equity (T.R.A.D.E.); UNCTAD: New York, NY, USA, 1999 (working paper). Available online: http://www.biosecurity.govt.nz/files/biosec/policylaws/intl/sps/resources/international/dc-issues.pdf (accessed on 20 February 2012).

36. United States-Certain Measures Affecting Imports of Poultry from China; Panel Report; WT/DS392/R, 25 October 2010.

37. Johnson, R.; Becker, G.S. Congressional Research Service: China-U.S. Poultry Dispute 2010. Congressional Research Service: Washington, DC, USA, 2010. Available online: http://www.nationalaglawcenter.org/assets/crs/R40706.pdf (accessed on 20 February 2012).

38. World Trade Organization Appellate Body. European Communities- Measures Affecting Asbestos and Asbestos-containing Products; World Trade Organization Appellate Body: Geneva, Switzerland, 2002; WT/DS135/AB/R (March 12, 2001), ๆ 172.

39. WHO. International Health Regulations (IHR), 2nd ed.; WHO: Geneva, Switzerland, 2005. Available online: http://whqlibdoc.who.int/publications/2003/9241591013.pdf (accessed 13 March 2012).

40. WHO. Review Committee on the Functioning of the IHR, 2011; WHO: Geneva, Switzerland, 2005. Available online: http://www.who.int/ihr/en/ (accessed on 13 March 2012).

41. Lin, T. The forgotten role of WHO/international health regulations in trade responses to 2009 A/H1N1 influenza outbreak. J. World Trade 2010, 40, 515-543.

42. Fidler, D.P.; Gostin, L.O. The new international health regulations: An historic development for international law and public health. J. Law Med. Ethics 2006, 34, 85-94.

43. Barton, J.H.; Emanuel, E.J. The patents-based pharmaceutical development process: Rationale, problems, and potential reforms. J. Am. Med. Assoc. 2005, 294, 2075-2082.

44. Commission on Intellectual Property Rights, Innovation and Public Health. Public Health: Innovation and Intellectual Property Rights: Report of the Commission on Intellectual Property Rights, Innovation and Public Health; WHO: Geneva, Switzerland, 2006.

45. Samnang, C. Case study: How do international trade agreements influence the promotion of public health? Yale J. Health Policy Law Ethics 2004, 4, 337-373.

46. Sapsin, J.W.; Thompson, T.M.; Stone, L.; DeLand, K.E. International trade, law and public health advocacy. J. Law. Med Ethics 2003, 31, 546-556.

47. Finger, J.M. The Doha Agenda and Development: A View from the Uruguay Round; Asian Development Bank: Manilla, Philippines, 2002.

48. Finger, J.M.; Schuler, P. Poor People's Knowledge: Promoting Intellectual Property in Developing Countries; The World Bank and Oxford University Press: Washington, DC, USA, 2004. 
49. Correa, C. Implementing TRIPS in Developing Countries. Third World Network: Penang, Malaysia, 1998. Available online: http://www.twnside.org.sg/title/ment-cn.htm (accessed on 30 October 2011).

50. Bipartisan Trade Promotion Authority Act, 19 U.S.C. $\S 3802(b)(4(A)(i)(I I)(2004)$.

51. Kennedy, E.; Waxman, H. Senator Kennedy and Representative Waxman requested an investigation into the Bush administration's trade negotiation practices and their negative effects on developing countries' access to medicine. U.S. Trade Agreements and International Health: Washington, DC, USA, 13 October 2006. Available online: http://oversight-archive.waxman. house.gov/documents/20061013141056-59889.pdf (accessed on 23 October 2011).

52. Chan, M. Creating Synergies between Intellectual Property Rights and Public Health, Opening remarks to the WHO-WIPO-WTO Joint Technical Symposium: Access to Medicines: Pricing and Procurement Practices. WTO: Geneva, Switzerland, 16 July 2010. Available online: http://www.wto.org/english/tratop_e/trips_e/techsymp_july10_e/techsymp_july10_e.htm (accessed on 20 February 2012).

53. Lamy, P. Strengthening Multilateral Cooperation on IP and Public Health, Address to the WIPO Conference on Intellectual Property and Public Policy Issues. WTO: Geneva, Switzerland, 14 July 2009. Available online: http://www.wto.org/english/news_e/sppl_e/sppl131_e.htm (accessed on 19 May 2011).

54. Smith, R.; Lee, K.; Drager, N. Trade and health: An agenda for action. Lancet 2009, 373, 768-773.

55. WHO. News release: Climate Change Will Erode Foundations of Health. WHO: Geneva, Switzerland, 7 April 2008. Available online: http://www.who.int/mediacentre/news/releases/ 2008/pr11/en/ (accessed on 30 June 2011).

56. WHO. Preventing Disease through Healthy Environments: Towards an Estimate of the Environmental Burden of Disease. WHO: Geneva, Switzerland, Available online: http://www.who.int/quantifying_ehimpacts/publications/prevdisexecsume.pdf (accessed on 20 February 2012).

57. Vidal, J. Global warming causes 300,000 deaths a year, says Kofi Annan think tank. Guardian London, May 29, 2009.

58. Mutunga, C.; Hardee, K.; Mogelgaard, K. Enhancing cooperation between the health and climate sectors. Bull At. Sci. 2009. Available online: http://thebulletin.org/web-edition/features/ enhancing-cooperation-between-the-health-and-climate-sectors (accessed on 20 February 2012).

59. Parry, M.L.; Canziani, O.F.; Palutikof, J.P.; van der Linden, P.J.; Hanson, C.E. Climate Change 2007: Impacts, Adaptation and Vulnerability; Cambridge University Press: Cambridge, UK, 2007.

60. World Bank. World development report 2010: Development and climate change. Clim. Dev. 2010, 2, 299-301. Available online: http://siteresources.worldbank.org/INTWDR2010/ Resources/5287678-1226014527953/WDR10-Full-Text.pdf (accessed on 20 February 2012).

61. Intergovernmental Panel on Climate Change. Climate Change and Water: IPCC Technical Paper VI. Intergovernmental Panel on Climate Change: New York, NY, USA, 2008. Available online: http://www.ipcc.ch/pdf/technical-papers/climate-change-water-en.pdf (accessed on 20 February 2012). 
62. Oxfam International. Horn of Africa Drought: Climate Change and future impacts on food security. Oxfam International: Oxford, UK, 2011. Available online: http://www.oxfam.org/en/ grow/policy/horn-africa-drought-climate-change-and-future-impacts-food-security (accessed on 7 February 2012).

63. Confalonieri, U.; Menne, B.; Akhtar, R.; Ebi, K.L.; Hauengue, M.; Kovats, R.S.; Revich, B.; Woodward, A. Human Health. In Climate Change 2007: Impacts, Adaptation and Vulnerability; Parry, M.L., Canziani, O.F., Palutikof, J.P., van der Linden, P.J., Hanson, C.E., Eds.; Cambridge University Press: Cambridge, UK, 2007; pp. 399, 413.

64. International Crisis Group. Climate Change and Conflict. Available online: http://www.crisisgroup.org/en/key-issues/climate-change-and-conflict.aspx (accessed on 20 February 2012). (invalid link)

65. Takacs, D. Carbon into gold: Forest carbon offsets, climate change adaptation, and international law. Hastings West-Northwest J. Environ. Law Policy 2009, 15, 57.

66. Afrane, Y.A.; Little, T.J.; Lawson, B.W.; Githeko, A.K.; Yan, G. Deforestation and vectorial capacity of anopheles Gambiae Giles mosquitoes in Malaria Transmission, Kenya. Emerg. Infect. Dis. 2008, 14, 1533-1538.

67. Hance, J. Losing nature's medicine cabinet. Mongabay 2010. Available online: http://news.mongabay.com/2010/1004-hance_herndon.html (accessed on 20 February 2012).

68. WHO. Climate Change and Health: Biodiversity. WHO: Geneva, Switzerland. Available online: http://www.who.int/globalchange/ecosystems/biodiversity/en/ (accessed on 20 February 2012).

69. Fidler, D.P. International Law and Public Health: Material on and Analysis of Global Health Jurisprudence; Transnational Publishers: New York, NY, USA, 2000; p. 369.

70. Fahey, D.W. Twenty Questions and Answers about the Ozone Layer: 2006 Update. NOAA ESRL CSD: Boulder, CO, USA, 2006. Available online: http://ozone.unep.org/ Assessment_Panels/SAP/Scientific_Assessment_2006/Twenty_Questions.pdf (accessed on 20 February 2012).

71. United Nations Environment Programme Ozone Secretariat. Status of Ratification. United Nations Environment Programme Ozone Secretariat: New York, NY, USA, 2012. Available online: http://ozone.unep.org/new_site/en/treaty_ratification_status.php (accessed on 20 February 2012).

72. Whatever happened to the Ozone Hole? National Geographic News: Washington, DC, USA, 5 May 2010. Available online: http://news.nationalgeographic.com/news/2010/05/100505science-environment-ozone-hole-25-years/ (accessed on 20 February 2012).

73. United Nations Framework Convention on Climate Change. Status of Ratification of the Convention. United Nations Framework Convention on Climate Change: Bonn, Germany, 1992. Available online: http://unfccc.int/essential_background/convention/status_of_ratification/items/ 2631.php (accessed on 30 June 2011).

74. Bals, C. Between Poznan and Copenhagen: The Climate Train in the "Valley of Death". Germanwatch e.V.: Bonn, Germany, 2008. Available online: http://www.germanwatch.org/klima/ c14rese.pdf (accessed on 20 February 2012). 
75. Muller, B. The Nairobi Climate Change Conference: A breakthrough for adaptation funding. Oxford Energy and Environment Comment, Oxford Institute for Energy Studies: Oxford, UK, 2007. Available online: http://www.oxfordenergy.org/wpcms/wp-content/uploads/2011/01/ Jan2007-NairobiClimateChang-Conference-BenitoMuller.pdf (accessed on 20 February 2012)

76. Fidler, D.P. International Law and Infectious Diseases; Clarendon Press: Oxford, UK, 1999, p. 269.

77. Von Schirnding, Y.; Onzivu, W.; Adede, A.O. International environmental law and global public health. Bull. WHO 2002, 80, 970-974.

78. United Nations Framework Convention on Climate Change, U.N. Doc. A/AC.237/18 (Part II)/Add.1. Entered into Force 9 May 1992; art. 1, P (1); art. 5, P (a)-(b). Available online: http://unfccc.int/resource/docs/convkp/conveng.pdf (accessed on 20 February 2012).

79. House Speaker Nancy Pelosi. Pelosi Leads Bipartisan Delegation to Copenhagen. Nancy Pelosi: Washington, DC, USA, 16 December 2009. Available online: http://pelosi.house.gov/news/ press-releases/2009/12/releases-Dec09-hagen.shtml (accessed on 20 February 2012).

80. The White House. President to Attend Copenhagen Climate Talks. The White House: Washington, DC, USA, 25 November 2009. Available online: http://geneva.usmission.gov/2009/11/25/obama-copenhagen/ (accessed on 8 February 2012).

81. WHO. Climate Change and Health, Resolution WHA 61.19. WHO, Geneva, Switzerland, 2008. Available online: http://www.who.int/globalchange/A61_R19_en.pdf (accessed on 20 February 2012).

82. WHO; UNEP. Health Environment: Managing the Linkages for Sustainable Development: A Toolkit for Decision-Makers. WHO: Geneva, Switzerland, 2008. Available online: http://whqlibdoc.who.int/publications/2008/9789241563727_eng.pdf (accessed on 20 February 2012).

83. Liggans, F. Climate Change and Health. Met Office: Exeter, UK, 2008. Available online: http://www.metoffice.gov.uk/media/pdf/2/j/transcript-climate-change-health.pdf (accessed on 9 November 2011).

84. Global Warming Climate Change Forecasts - 2040. Available online: http://www.globalwarming-forecasts.com/2040-climate-change-global-warming-2040.php (accessed on 9 November 2011).

85. WHO. Climate and Health: Fact Sheet No. 266; WHO: Geneva, Switzerland, 2011. Available online: http://www.who.int/mediacentre/factsheets/fs266/en/ (accessed on 9 November 2011).

86. What Is Biodiversity? Center for Biodiversity and Conservation American Museum of Natural History: New York, NY, USA, 2011. Available online: http://cbc.amnh.org/center/what.html (accessed on 27 October 2011).

87. Neira, M.; Campbell-Lendrum, D. Saving lives, saving money. World Conserv. 2009, 39, 24-26.

88. Ki-moon, B. My Priorities as Secretary General. Available online: http://www.europarl. europa.eu/meetdocs/2009_2014/documents/afet/dv/201/201010/20101019_mypriorities_en.pdf (accessed on 20 February 2012).

89. WHO. Indoor Air Pollution and Health: Fact sheet No. 292; WHO: Geneva, Switzerland, 2011. Available online: http://www.who.int/mediacentre/factsheets/fs292/en/index.html (accessed on 9 November 2011). 
90. WHO. Fuel for Life: Household Energy and Health; WHO: Geneva, Switzerland, 2006. Available online: http:/www.who.int/indoorair/publications/fuelforlife.pdf (accessed on 9 November 2011).

91. Fuel for Life: Household Energy and Health; WHO: Geneva, Switzerland, 2006; p. 24. Available online: http://www.who.int/indoorair/publications/fuelforlife.pdf (accessed on 9 November 2011).

92. Boutros-Ghali, B. Secretary-General of the United Nations, Opening Statement, 1996 World Food Summit. Available online: http://www.fao.org/wfs/ (accessed on 24 August 11).

93. Food and Agriculture Organization of the United Nations. The State of Food Insecurity in the World 2010; FAO: Rome, Italy, 2010. Available online: http://www.fao.org/docrep/ 013/i1683e/i1683e00.htm (accessed on 20 February 2012).

94. Pelletier, D.L.; Frongillo, E.A., Jr.; Schroeder, D.G.; Habicht, J.P. The Effects of Malnutrition on Child Mortality in Developing Countries. Bull. WHO 1995, 73, 443-448.

95. Food and Agriculture Organization of the United Nations. The State of Food Insecurity in the World 2010; FAO: Rome, Italy, 2010. Available online: http://www.fao.org/docrep/ 013/i1683e/i1683e00.htm (accessed on 20 February 2012).

96. Victora, C.G.; Adair, L.; Fall, C.; Hallal, P.C.; Martorell, R.; Richter, L.; Sachdev, H.S.; the Maternal and Child Undernutrition Study Group. Maternal and child undernutrition: consequences for adult health' and human capital. Lancet 2008, 371, 340-357.

97. Blössner, M.; de Onis, M. Malnutrition: Quantifying the Health Impact at National and Local Levels; WHO: Geneva, Switzerland, 2005.

98. World Food Summit 1996. Rome Declaration on World Food Security. Available online: http://www.fao.org/wfs/index_en.htm (accessed on 20 February 2012).

99. Food and Agriculture Organization of the United Nations. The State of Food Insecurity in the World: High Food Prices and Food Security-Threats and Opportunities, 2008. Available online: ftp://ftp.fao.org/docrep/fao/011/i0291e/i0291e00.pdf (accessed on 20 February 2012).

100. Agreement on Agriculture, 15 April 1994. Marrakesh Agreement Establishing the World Trade Organization, Annex 1A, The Legal Texts: The Results of the Uruguay Round of Multilateral Trade Negotiations 33 (1999), 1867 U.N.T.S. 410.

101. Kaufman, C.; Heri, S. Liberalizing Trade in Agriculture and Food Security-Mission Impossible? Vand. J.Transnat'l.L. 2007, 40, 1039-1070.

102. Dugger, C.W. As Prices Soar, U.S. Food Aid Buys Less. New York Times New York, September 29, 2007.

103. Mousseau, F. Food Aid or Food Sovereignty? Ending World Hunger in Our Time. Oakland Institute, October 2005. Available online: http://www.oaklandinstitute.org/sites/oaklandinstitute. org/files/fasr.pdf (accessed on 20 February 2012).

104. World Food Programme. Responding to Emergencies. Available online: http://www.wfp.org/ emergencies (accessed on 20 February 2012).

105. Food Aid Convention, 1999. Entered into Force 1 July 1999. Available online: http://www.fao.org/Legal/rtf/fac99-e.htm (accessed on 20 February 2012).

106. What Is the CERF? Available online: http://ochaonline.un.org/cerf/WhatistheCERF/tabid/3534/ language/en-US/Default.aspx (accessed on 10 November 2011). 
107. Donors. Available online: http://ochaonline.un.org/cerf/Donors/Donors/tabid/5370/language/enUS/Default.aspx (accessed on 10 November 2011).

108. Oxfam International, Press Release - Governments are failing to support global emergency fund ahead of today's UN debate, 22 November 2005. Available online: http://www.oxfam.org/ en/news/pressreleases2005/pr051116_un_aid_fund (accessed on 10 November 2011).

109. Special Investigation: Understanding Land Investment Deals in Africa. Available online: http://www.oaklandinstitute.org/special-investigation-understanding-land-investment-deals-africa (accessed on 11 November 2011).

110. Huber, M. The Red Cross-Principles and Problems; A. Kundig Press: Geneva, Switzerland, undated, as cited in Meurant, J. Inter Arma Caritas: Evolution and Nature of International Humanitarian Law. JPR 1987, 24, 237-249.

111. Arya, N.; Santa Barbara, J. Peace Through Health: How Health Professionals Can Work for a Less Violent World; Kumarian Press: Bloomfield, CT, USA, 2008; p. 49.

112. Arya, N. Peace through Health? In Handbook of Peace and Conflict Studies; Webel, C., Galtung, J., Eds.; Routledge: Oxford, UK, 2007; p. 367.

113. Libyan Capital Faces Health Disaster as Aid Held Up. Reuters London, August 24, 2011.

114. Hynes, H.P. Over the battlefield of women's bodies: An overview of the harm of war to women. Women Stud. Int. Forum. 2004, 27, 431-445.

115. Toole, M.J.; Galson, S.; Brady, W. Are war and Public Health Compatible? Lancet 1993, 341, 1193-1196.

116. Garfield, R.M.; Neugut, A.I. The Human Consequences of War. In War and Public Health; Levy, B.S., Sidel, V.W., Eds.; American Public Health Association: Washington, DC, USA, 2000; pp. 27-38.

117. Human Rights Watch. Bahrain: Targets of Retribution: Attacks Against Medics, Injured Protesters, and Health Facilities; Human Rights Watch: New York, NY, USA, 2011.

118. Physicians for Social Responsibility. Health Effects of War: Seeking SMART Security. Available online: action.psr.org/site/DocServer/HEWHandoutSMART.doc?docID (accessed on 8 February 2012).

119. Ghobarah, H.A.; Huth, P.; Russet, B. The post-war public effects of civil conflict. Soc. Sci. Med. 2004, 59, 869-884.

120. Ashford, M.; Huet-Vaughn, Y. The Impact of War on Women. In War and Health; Levy, B.S., Sidel, V.W., Eds.; American Public Health Association: Washington, DC, USA, 2000.

121. Vajpeyi, D.K. Deforestation, Environment, and Sustainable Development: A Comparative Analysis; Praeger Publishers: Westport, CT, USA, 2001.

122. Enzler, E.M. Environmental Effects of Warfare. Available online: http://www.lenntech.com/ environmental-effects-war.htm (accessed on 8 February 2012).

123. ICRC. War and international humanitarian law. Available online: http://www.icrc.org/eng/warand-law/overview-war-and-law.htm (accessed on 20 February 2012).

124. Dunant, H. A Memory of Solferino; International Committee of the Red Cross: Geneva, Switzerland, 1986. 
125. Beaumont, A. IRIC Hails Ratification of Geneva Conventions. Available online: http://www.swissinfo.ch/eng/ICRC_hails_ratification_of_Geneva_Conventions.html?cid=3716 (accessed on 4 November 2011).

126. Much of international humanitarian law is also considered to have become customary law. Customary IHL database. Available online: http://www.icrc.org/customary-ihl/eng/docs/home (accessed on 4 November 2011).

127. Mission of the ICRC. Available online: http://www.icrc.org/HOME.NSF/060a34982cae624ec 12566fe00326312/125ffe2d4c7f68acc1256ae300394f6e?OpenDocument (accessed on 20 February 2012).

128. Shah, A. Small Arms - They Cause 90\% of Civilian Casualties. Global Issues January 21, 2006. Available online: http://www.globalissues.org/article/78/small-arms-they-cause-90-of-civiliancasualties\#SmallArmsCauseMassDestruction (accessedon 10 November 2011). (Citing the International Action Network on Small Arms, which has used the term "weapons of mass destruction" for small arms).

129. Geneva Declaration on Armed Violence and Development. What Is the Declaration? Available online: http://www.genevadeclaration.org/the-geneva-declaration/what-is-the-declaration.html (accessed on 10 November 2011).

130. Geneva Declaration on Armed Violence and Development. In Global Burden of Armed Violence 2011; Geneva Declaration on Armed Violence and Development: Geneva, Switzerland, 2011; p. 4. Available online: http://www.genevadeclaration.org/measurability/global-burden-of-armedviolence/global-burden-of-armed-violence-2011.html (accessed on 10 November 2011).

131. Programme of Action to Prevent, Combat and Eradicate the Illicit Trade in Small Arms and Light Weapons in All Its Aspects, UN Document A/CONF.192/15 (2001). Available online: http://www.poa-iss.org/PoA/poahtml.aspx (accessed on 10 November 2011).

132. United Nations. Small Arms: Report of the Secretary-General. UN doc. S/2011/255, 5 April 2011.

133. An Arms Trade Treaty being negotiated in mid-2012 may cover small arms. International Action Network on Small Arms. The Arms Trade Treaty: Useful Documents and Initiatives Relative to Africa: Prepared by IANSA for the African Union Expert Meeting to Elaborate an ATT Common Position, Lome, Togo, 28-29 September 2011; International Action Network on Small Arms: London, UK, 2011. Available online: http:/www.iansa.org/system/files/Final\%20English.pdf (accessed on 10 November 2011).

134. Achiron, M.; UNHCR. A 'timeless' treaty under attack. Refugees 2001, 2, 7. Available online: http://www.unhcr.org/3b5e90ea0.html (accessed on 20 February 2012).

135. Toole, M.J.; Waldman, R.J. The public aspects of complex emergencies and refugee situations. Annu. Rev. Public Health 1997, 18, 283-312. Available online: http:/www.annualreviews.org/ doi/full/10.1146/annurev.publhealth.18.1.283 (accessed on 20 February 2012).

136. WHO. Health action in crises-Health response to the earthquake in Haiti: January 2010. Available online: http://www.who.int/hac/crises/hti/en/ (accessed on 20 February 2012). 
137. DeNoon, D.J. Hurricane Katrina: Health Aftermath - What to Expect, How to Cope. Available online: http://www.webmd.com/news/20050831/hurricane-katrina-health-aftermath (accessed on 20 February 2012).

138. Rosenberg, T. Refugee Camps, the Price of Dignity. New York Times New York, 1 September 2011.

139. Rosenberg, T. Beyond Refugee Camps, a Better Way. New York Times September 6, 2011.

140. Convention relating to the Status of Refugees, 189 U.N.T.S. 150. Entry into Force 22 April 1954; article 1A, article 33(1).

141. Committee on Economic, Social and Cultural Rights, 22nd Session, General Comment No. 14: The Right to the Highest Attainable Standard of Health, U.N. Doc. E/C.12/2000/4, 11 August 2000; article 12.

142. Jastram, K.; Achiron, M. Refugee Protection: A Guide to International Refugee Law; UN High Commissioner for Refugees: Geneva, Switzerland, 2001.

143. United Nations Treaty Collection. Status of Treaties: International Convention on the Protection of the Rights of All Migrant Workers and Members of their Families. Available online: http://treaties.un.org/pages/ViewDetails.aspx?src=TREATY\&mtdsg_no=IV-13\&chapter= 4\&lang=en (accessed on 20 February 2012).

144. International Organization for Migration. The Global Campaign for Ratification of the Convention on Rights of Migrants. 20th Anniversary Ratification Campaign. Available online: http://www.migrantsrights.org/ (accessed on 8 February 2012).

145. U.N. G.A. res. 3274 XXIX, U.N. Doc. A/RES/3274(XXIX) (10 December 1974).

146. UNHCR. Internally Displaced People: On the Run in Their Own Land. Available online: http://www.unhcr.org/pages/49c3646c146.html (accessed on 20 February 2012).

147. Cohen, R. The guiding principles on internal displacement: An innovation in international standard setting. Glob. Gov. 2004, 10, 459-480.

148. UN High Commissioner for Refugees, Guiding Principles on Internal Displacement, E/CN.4/1998/53/Add.2, 22 July 1998; principle 18 and principle 19.

149. U.N. G.A. res 60/1, U.N Doc. A/RES/60/1 (24 October 2005).

150. Deng, F. A decade in human rights law; international response to international displacement: A revolution in the making. Hum. Rights Brief 2004, 11, 25.

151. African Union. African Union Convention for the Protection and Assistance of Internally Displaced Persons in Africa ("Kampala Convention"), 22 October 2009; article 9(2).

152. Bell, M.L.; Davis, D.L.; Fletcher, T. A retrospective assessment of mortality from the London smog episode of 1952: the role of influenza and pollution. Environ. Health Persp. 2004, 112, 6-8.

153. Osborn, M. Uplands downwind: Acidity and ecological change in the Southeast Lancashire Moorlands. In Smoke and Mirrors: The Politics and Culture of Air Pollution; DuPuis, E.M., Ed.; New York University Press: New York, NY, USA, 2004.

154. Environmental History Timeline, World War II and the Postwar Years. Available online: http://www.radford.edu/ wkovarik/envhist/7forties.html (accessed on 20 February 2012). 
155. United Nations, The Report of the United Nations Secretary-General's High-Level Panel on Global Sustainability, 2011. Available online: http://www.un.org/gsp/report (accessed on 20 February 2012).

(C) 2012 by the authors; licensee MDPI, Basel, Switzerland. This article is an open access article distributed under the terms and conditions of the Creative Commons Attribution license (http://creativecommons.org/licenses/by/3.0/). 